\title{
Plasma Proteins in Health and Disease: A Scientific Symposium to Celebrate the Career and Accomplishments of Harvey R. Colten, M.D.
}

\author{
JULIO PEREZ FONTAN, S. BRUCE DOWTON, DAVID PERLMUTTER, JONATHAN GITLIN, AND F. SESSIONS COLE
}

\begin{abstract}
Department of Pediatrics [J.P.F.], University of Texas Southwestern School of Medicine and Children's Medical Center of Dallas, Dallas, TX 75390; Department of Pediatrics [S.B.D.], Columbia University Medical Center, New York, NY 11032; Department of Pediatrics [D.P.], University of Pittsburgh School of Medicine and Pittsburgh Children's Hospital, Pittsburgh, PA 15213; Edward Mallinckrodt Department of Pediatrics [J.G., F.S.C.], Washington University School of Medicine, and St. Louis Children's Hospital, St. Louis, MO 63110
\end{abstract}

In October 2005, a large group of colleagues, former students, friends, and family gathered at Washington University in St. Louis at a scientific symposium to honor Harvey Colten and celebrate his many scientific accomplishments and contributions to pediatric medicine. The Journal has been kind enough to join in this tribute by publishing the contribution made to the Symposium by one of Colten's most distinguished students, David Perlmutter.

Harvey Colten will be retiring this year from his current position as Vice President and Senior Associate Dean for the Faculties of Health Sciences and Medicine at Columbia University. Many of us know well that, for Colten, retirement simply signals the opportunity to attack some larger projects that have been waiting. For the rest of us, the St. Louis Symposium [together with the recent passing of Fred Rosen (1930-2005, see Obituary in Nature 435:1044, 2005)] has given us a chance to remember how much pediatrics owes to the small number of clinician-scientists who gathered around Charles Janeway and continued in his quest to understand the biologic underpinnings of human immune disease. Harvey Colten was the youngest of the group and, in the words of Fred Rosen himself, a perfect representation of the intrepid spirit that animated them all. Just like the others, Colten shared the fundamental insight that hereditary immune disorders, no matter how rare and complex, give us a unique chance to pry into the folds of the immune system and its development.

Following this insight, Colten adopted the new techniques brought by the cellular and molecular revolution to understand not only the regulation and deficiencies of the complement system, but also a large variety of important biologic issues

Received January 18, 2006; accepted January 18, 2006.

Correspondence: F. Sessions Cole, M.D., Division of Newborn Medicine, St. Louis Children's Hospital, One Children's Place, St. Louis, MO 63110; e-mail: cole@kids.wustl.edu

The Symposium was sponsored by the Edward Mallinckrodt Department of Pediatrics of Washington University School of Medicine, St. Louis Children's Hospital, Washington University School of Medicine, and Columbia College of Physicians and Surgeons.

DOI: 10.1203/01.pdr.0000228332.38159.4f that attracted his attention over the years, from leukocyte adhesion molecules, to extrahepatic synthesis of plasma proteins, to the biology of pulmonary surfactant. In reviewing the literature on complement, it is impossible not to run into Harvey Colten's footprints. His laboratory discovered that not only can complement be synthesized outside the liver (1-3), but that its synthesis is regulated locally by inflammation (4). Colten perfected the techniques to study complement synthesis and secretion in isolated cells and went on to apply these techniques to elucidate the genetic and biosynthetic defects that cause spontaneous C2 (5), C3 (6,7), C4 (8), and C5 (9) deficiencies in humans and animals. He delineated the unique events involved in the posttranslational processing of $\mathrm{C} 4$ (10), setting the stage for the analysis of similar processes involving $\mathrm{C} 3$ and $\mathrm{C} 5$.

Colten's large body of work has changed how we view the pathogenesis of inflammation and the mechanisms of host defense. His laboratory isolated and characterized the human cDNA clone for human C-reactive protein (11) and established the role of interleukin- 1 and other cytokines in mediating the hepatic acute phase inflammation (12). Colten's findings provided novel insights into the posttranslational processing and degradation of proteins, which led to other paradigm shifting discoveries such as the discovery of the mechanism of hepatocellular damage in $\alpha_{1}$-antitrypsin deficiency by David Perlmutter (13). Along the way, focused as his research was, Colten always demonstrated enormous peripheral vision and a sense of opportunity to attack other problems of biologic or clinical importance. A good example is his early realization of the potential for the use of anti-inflammatory agents in cystic fibrosis $(14,15)$, which today we take for granted. Another one is the identification of an integrin deficiency (then named gp150) as the cause of neutrophil dysfunction (16), inaugurating the hunting season for adhesion molecule defects as a cause for immune dysfunction. Finally, and while he was already Chairman of Pediatrics at Washington University, Harvey's team discovered and characterized surfactant protein B deficiency as a novel mechanism for respiratory distress of the 
mature newborn, putting an end to a long-standing puzzle in newborn medicine (17).

In addition to his scientific contributions, Harvey Colten has created a legacy of leadership in American pediatrics. He became the Harriet B. Spoehrer Professor and Chairman of Pediatrics at Washington University in 1986. Over the subsequent $10 \mathrm{y}$, he built one of the best departments of pediatrics in the country. His success was as much a result of his personality as it was of his method. Harvey is convincing because he is convinced. Combine that with a lucid mind, an eagerness to engage in intellectual discussion, and a personal presence that can fill a stadium, and you can understand how he could lead and inspire a most extraordinary and undisciplined group of young physician-scientists. Harvey also knew how important it is for a department of pediatrics to attract the respect and admiration of the larger university community and the hospital governing organizations. He did that by showing an unwavering commitment to scholarly quality and by expecting as much from his department as anybody would expect from the best department in the school.

Always the academician, Colten has exercised a great deal of influence over both developmental science and the education of pediatricians through participation in multiple national organizations, from the National Institute of Allergy and Infectious Disease and National Heart, Lung, and Blood Insitute, to the National Cystic Fibrosis Foundation, to the Institute of Medicine, where he has animated a large number of child-related initiatives. Harvey has been an essential contributor to pediatric advisory boards and councils, task forces, and national committees. In all these functions, he has served as a voice of reason and as a staunch defender of the academic values that informed his own career. His interest in furthering the frontiers of medical practice and medical education took him to become a Dean (at Northwestern University), and corporate officer (at iMetrikus), and more recently a Vice President (at Columbia Medical College). His heart, however, has remained attached to St. Louis and his role as pediatric chairman. The Department of Pediatrics has recognized this attachment by creating a Harvey Colten Award, which is given to those graduates from the residency program who go on to achieve notable academic success.

Harvey Colten exemplifies the accomplishments, values, and vision that are so vital for the permanence of our discipline in these times of serious disorientation. We look forward to his future contributions, which this time will be made from his adopted home in New Hampshire, where he will be sharing his time with his wife and best advisor Sue Colten.

\section{REFERENCES}

1. Colten HR 1972 Ontogeny of the human complement system: in vitro biosynthesis of individual complement components by fetal tissues. J Clin Invest 51:725-730

2. Colten HR, Gordon JM, Borsos T, Rapp HJ 1968 Synthesis of the first component of human complement in vitro. J Exp Med 128:595-604

3. Colten HR, Borsos T, Rapp HJ 1966 In vitro synthesis of the first component of complement by guinea pig small intestine. Proc Natl Acad Sci U S A 56:1158-1163

4. Ruddy S, Colten HR 1974 Rheumatoid arthritis: biosynthesis of complement proteins by synovial tissues. N Engl J Med 290:1284-1288

5. Einstein LP, Alper CA, Bloch KJ, Herrin JT, Rosen FS, David JR, Colten HR 1975 Biosynthetic defect in monocytes from human beings with genetic deficiency of the second component of complement. N Engl J Med 292:1169-1171

6. Auerbach HS, Burger R, Dodds A, Colten HR 1990 Molecular basis of complement C3 deficiency in guinea pigs. J Clin Invest 86:96-106

7. Morris KM, Goldberger G, Colten HR, Aden DP, Knowles BB 1982 Biosynthesis and processing of a human precursor complement protein, pro-C3, in a hepatomaderived cell line. Science 215:399-400

8. Colten HR, Parkman R 1972 Biosynthesis of C4 (fourth component of complement) by hybrids of C4-deficient guinea pig cells and HeLa cells. Science 176:1029-1031

9. Ooi YM, Colten HR 1979 Genetic defect in secretion of complement C5 in mice. Nature 282:207-208

10. Goldberger G, Colten HR 1980 Precursor complement protein (pro-C4) is converted in vitro to native C4 by plasmin. Nature 286:514-516

11. Whitehead AS, Bruns GA, Markham AF, Colten HR, Woods DE 1983 Isolation of human C-reactive protein complementary DNA and localization of the gene to chromosome 1. Science 221:69-71

12. Perlmutter DH, Goldberger G, Dinarello CA, Mizel SB, Colten HR 1986 Regulation of class III major histocompatibility complex gene products by interleukin-1. Science 232:850-852

13. Perlmutter DH, Kay RM, Cole FS, Rossing TH, Van Thiel D, Colten HR 1985 The cellular defect in alpha 1-proteinase inhibitor (alpha 1-PI) deficiency is expressed in human monocytes and in Xenopus oocytes injected with human liver mRNA. Proc Natl Acad Sci U S A 82:6918-6921

14. Auerbach HS, Williams M, Kirkpatrick JA, Colten HR 1985 Alternate-day prednisone reduces morbidity and improves pulmonary function in cystic fibrosis. Lancet 2:686-688

15. Matthews WJ Jr, Williams M, Oliphint B, Geha R, Colten HR 1980 Hypogammaglobulinemia in patients with cystic fibrosis. N Engl J Med 302:245-249

16. Arnaout MA, Pitt J, Cohen HJ, Melamed J, Rosen FS, Colten HR 1982 Deficiency of a granulocyte-membrane glycoprotein $(\mathrm{gp} 150)$ in a boy with recurrent bacterial infections. N Engl J Med 306:693-699

17. Nogee LM, de Mello DE, Dehner LP, Colten HR 1993 Brief report: deficiency of pulmonary surfactant protein B in congenital alveolar proteinosis. N Engl J Med 328:406-410 